\title{
Introduction to the Special Issue: Out for Blood: Sacrifice, Tantra, and Normative Hinduism
}

\author{
Sravana Borkataky-Varma
}

Published online: 21 June 2019

(C) Springer Nature B.V. 2019

This project emerged out of a shared passion for the study of bali, the Hindu religious sacrifice. The collection of essays in this special issue was first conceptualized by Joel Bordeaux for a panel at the American Academy of Religions. After a successful panel presentation, Hugh B. Urban suggested that we explore publishing our papers as a special issue edition. And so began the journey from conception to delivery. The other three authors thank Joel for the idea and Hugh for proposing a way forward.

The theme of religious sacrifice is not new to the academic study of religions. Extensive debates can be found on the very definition of the term. The subject has captured the interest of a wide range of scholars: anthropologists, sociologists, historians, ethnographers, and so forth. In addition, the practice of religious sacrifice is nearly universal across human cultures. Some scholars have sought to explain how sacrifice reenacts creation myths (James G. Frazer, Adolf E. Jensen), asserts control over life and death (René Girard, Maurice Bloch), displaces guilt (Sigmund Freud, Walter Burkert), or maintains relationships with deities (Edward Burnett Tylor, William Robertson Smith, Edward A. Westermark). Others focus on sacrifice as a means of engineering a shared experience of transcendence (Émile Durkheim, Georges Bataille, Victor Turner), perpetuating social structures and values (Valerio

Sravana Borkataky-Varma sravana.varma@gmail.com

Department of Philosophy and Religion, University of North Carolina Wilmington, $601 \mathrm{~S}$. College Road, Wilmington, NC 28403, USA 
Valeri, Bruce Lincoln, Nancy Jay), even shaping its technology (Jonathan Z. Smith) (Bordeaux 2017). ${ }^{1}$ A scan of these studies leads us to a set of questions that have been asked by scholars over time: What characterizes a sacrifice? What are the differences and similarities between sacrifice and religious ritual? Why is an emphasis on sacrifice so prevalent among religious traditions?

Henri Hubert and Marcel Mauss's collaborative work in 1898 "Essai sur la nature et la fonction du sacrifice" has served as a reference point for many studies on religious sacrifice (Carter 2006: 88). This seminal work provides the reader with a definition of sacrifice as well as exploring the motivations behind the offering of religious sacrifice. This revolutionary theory on sacrifice presented here viewed the ritual in the Vedic corpus with a biblical lens. Building on Hubert and Mauss, Kathryn McClymond (2008) provides a multipronged approach to the study of sacrifice. By critically analyzing vegetable and liquid offerings along with animal sacrifice, her study widens the sacrificial frame. McClymond makes the argument that scholarly approaches to religious sacrifice and related experiences have largely been shaped by Protestant Christian thought and that such an approach does not provide sufficient breadth to the study of religious sacrifice within different religions and cultures.

Borrowing from McClymond, bali in this issue is presented within the framework of three broad themes: sacrifice as a dramatized myth, sacrifice as exchange, and sacrifice as death or violence (McClymond 2008: 4). While feminist and structuralist approaches are alluded to, our goal here is rather to explore and reach an understanding of how religious sacrifice is understood in Hinduism. Together, these essays offer a rich perspective on the diverse ways in which religious sacrifice is perceived and interpreted within the tradition.

In the first essay, "Blood in the Mainstream: Kālī Pūjā and Tantric Orthodoxy in Early Modern Bengal," Joel Bordeaux emphasizes the interplay of Tantric and more classically Brāhmanical elements in Bengali Śākta ritual. Looking at the promotion of Kālī worship and the accompanying practice of religious sacrifice, especially by Hindu aristocrats such as Rāja Kṛ̣ṇacandra Rāya (1710-82), Bordeaux argues that such a move not only brought the goddess Kālī to the public popular domain in Bengal, but it also propagated a distinctly Tantricized Smārta Hinduism in the region.

The next essay, by Xenia Zeiler, entitled "Eradicated with Blood: Text and Context of Animal Sacrifice in Tantric and Tantra-Influenced Destructive Rituals," focuses on ritualized blood offerings in destructive and/or defensive Tantric uccātana rituals. The first part focuses on Dhūmāvatī and the uccātana practices. In the second part, Zeiler relates the uccātana practices to other deities connected to ojhāi, which is especially popular in North India, including animal sacrifice in

\footnotetext{
${ }^{1}$ It is not my intention to assert that the contributions of the authors mentioned above are reducible to the exceedingly brief glosses under which I have grouped them. Neither is this list presented as exhaustive, nor even essential. Others could be adduced as perhaps more representative of some of these perspectives, but for the reader's convenience I have restricted my examples to those names that appear in Carter's (2006) useful anthology of influential writing on the subject. Interested readers may also find the theoretical overview that opens McClymond's (2008) book helpful as a starting point.
} 
exorcism rituals. Zeiler thereby argues for a methodical plurality in researching Tantra and demonstrates how ethnography can complement textual analysis.

The second half of the issue explores sacrifice as a site of conflict and accommodation, first in the Northeast and then in the Western Himalayas. In "Red: An Ethnographic Study of Cross-Pollination of Vedic and Tantric in Sākta Assam," Sravana Borkataky-Varma explores the connections between Tantric rites and those of South Asian tribal religions, a link that scholars have often presumed but neglected to demonstrate. Drawing on her own fieldwork, she compares animal sacrifices at a local Śiva temple as practiced and understood by the indigenous Tiwā tribe with corresponding data gathered nearby at the famous śakti pịtha, Kāmākhyā. This essay thus concretizes and brings into relief some of the dynamics inherent in how these neighboring sacrificial traditions relate to each other, Vedic norms, sacred space, and recent challenges from animal rights activists.

The final essay by Ehud Halperin considers the impact of the tourist industry on the ongoing conflict over sacrifice in Himachal Pradesh. "Is the Goddess Hadimbā Tantric? Negotiating Power in a Western Himalayan Sacrificial Arena" highlights possible Tantric overtones in the personality and worship of Hadimbā, a local goddess associated with Durgā. Halperin situates Hadimbā and the practice of animal worship at the heart of the controversy that revolves around the long negotiations between peripheral mountain religion and mainstream Brāhmaṇic Hindu ideals. Halperin suggests further investigation and exploration of Haḍimbā in relation to the religious transformations that took place in the eighth-century Assam. The hypothesis proposed here is that if the rituals around Hadimbā map to the crosspollination of perpheral and mainstream religions in Assam, then it could reveal that Hadịimbā is a Tantric goddess after all.

Taken together, these four essays showcase how investigation of bali brings forth a broad, multivalent notion of sacrifice, which is intimately connected to both religious and regional identities.

\section{References}

Bordeaux, Joel. 2017. Unpublished Notes on Jeffrey Carter, ed., Understanding Religious Sacrifice: A Reader (New York: Continuum, 2006).

Carter, Jeffrey, ed. 2006 [2003]. Understanding Religious Sacrifice: A Reader. New York: Continuum.

Hubert, Henri and Marcel Mauss. 1898. "Essai sur la nature et la fonction du sacrifice." L'année sociologique 2: 29-138.

McClymond, Kathryn. 2008. Beyond Sacred Violence: A Comparative Study of Sacrifice. Baltimore: John Hopkins University Press.

\section{Publisher's Note}

Springer Nature remains neutral with regard to jurisdictional claims in published maps and institutional affiliations. 